\title{
PROCESSING TECHNOLOGY OF FLOTATION TAILINGS BY USING COMBINED FLOTATION REAGENTS
}

\author{
L. V. Semushkina ${ }^{1}$, D. K. Turysbekov ${ }^{1}$, N. K. Tussupbayev ${ }^{1}$, O. B. Kotova ${ }^{2}$ \\ ${ }^{1}$ Center of Earth Sciences, Metallurgy and Ore Beneficiation, Almaty, Kazakhstan; syomushkina.lara@mail.ru \\ ${ }^{2}$ Institute of Geology of Komi SC, UB RAS, Russia; kotova@geo.komisc.ru
}

We tested technologies of processing of flotation tailings by using combined flotation reagent on the example of tailings from Zhezkazgan plant and Tishinskoe deposit (Kazakhstan). The combined collector is a mixture of composite aerofloat, TS1000 and butyl xanthate with reactant ratios 1:1:3. The advantage of the suggested flotation reagent is its composition including two polar groups and a long hydrocarbon radical. We showed that the flotation of Zhezkazgan tailings using smaller consumption of combined reagent in comparison with butyl xanthate resulted in the draft copper concentrate with copper content $13.0 \%$ at recovery $80.22 \%$. In comparison with the base technology the content of copper in the draft concentrate increases at $5.1 \%$, and the recovery - increases at $31.4 \%$. At flotation of Tishinskoe deposit tailings the copper recovery into the collective concentrate increases at $9.63 \%$, lead - at $8.41 \%$; zinc - at $9.2 \%$.

Keywords: flotation tailings, regrinding, extraction, recovery.

\section{ТЕХНОЛОГИЧЕСКИЕ ОСНОВЫ ПЕРЕРАБОТКИ ХВОСТОВ ФЛОТАЦИОННОГО ОБОГАЩЕНИЯ С ПРИМЕНЕНИЕМ КОМБИНИРОВАННЫХ ФЛОТОРЕАГЕНТОВ}

\author{
Л. В. Семушкина ${ }^{1}$, Д. К. Турысбеков ${ }^{1}$, Н. К. Тусупбаев ${ }^{1}$, О. Б. Котова ${ }^{2}$ \\ ${ }^{1} \mathrm{AO}$ «Центр наук о земле, металлургии и обогашения», Алматы, Казахстан \\ ${ }^{2}$ Институт геологии Коми НЦ УрО РАН, Россия
}

\begin{abstract}
Апробированы технологии переработки хвостов флотационного обогащения с применением комбинированного флотореагента на примере Жезказганской фабрики и Тишинского месторождения (Казахстан).

Комбинированный собиратель представляет собой смесь композиционного аэрофлота, ТС-1000 и бутилового ксантогената. Соотношение реагентов составляет 1:1:3. Преимуществом предлагаемого флотореагента является то, что он имеет в своем составе две полярные группы и длинный углеводородный радикал. Показано, что при флотации Жезказганских хвостов с применением меньшего, по сравнению с бутиловым ксантогенатом, расхода комбинированного собирателя получен черновой медный концентрат с содержанием меди 13.0 \% при извлечении 80.22 \%. По сравнению с базовой технологией содержание меди в черновом концентрате повышается на 5.1 \%, извлечение на 31.4 \%. При флотации Тишинских хвостов с применением комбинированного собирателя извлечение меди в коллективный концентрат повышается на $9.63 \%$; свинца на $8.41 \%$; цинка на $9.2 \%$.
\end{abstract}

Ключевые слова: флотационные хвосты, доизмельчение, извлечение, комбинированный собиратель, флотация, концентрат.

\section{Introduction}

The industry largely uses xanthates, dialkyldithiophosphates and mercaptans for the flotation of sulfides, oxidized minerals of heavy non-ferrous metals, native and noble metals. For the selective extraction of over 40 minerals of heavy non-ferrous and noble metals with different physical and chemical properties only 56 types of sulfhydryl collectors are used at flotation.

We tested several new reagents out of many combinations of three major donor atoms $(\mathrm{S}, \mathrm{N}$ and $\mathrm{O})$ in the main group of bonds, including several complexing agents, as collectors; and the received results were actively discussed in numerous books and papers $[1-3]$.

The search and development of new more selective collecting reagents for the flotation process improvement is a priority when creating innovative technologies of flotation separation of substances and minerals. A large number of organic compounds were suggested as collectors, however, less 160 were used in practice [4]. The modern practice of application of collectors in the flotation of sulphide ores mainly involves xanthates and aerofloats. The additional application of aerofloats allows not only improving the quality of the sulphide concentrates due to a more selective action of the aerofloats, but also enhancing recovery of metals due to the ability of aerofloats to float fine particles efficiently.

The work [5] presented the results of laboratory researches and industrial tests on the use of hexyl xanthate of Hoechst company and mixtures with butyl and isopropyl xanthates at the flotation of sulfide copper minerals. The work showed technological and economic efficiency of application of hexyl and butyl xanthates mixture while reducing its consumption from 70 to $50 \mathrm{~g} / \mathrm{t}$. Copper recovery increased at $0.4 \%$.

As a more selective collector in the separation of pyrite and arsenopyrite it was suggested to use the reaction product of xanthate and propylene-chlorohydrin, which received the name of PROX reagent. The results of experimental studies of the collectors from the dialkyldithiophosphate class (aerofloats) indicate that their combined use with xanthates in many cases enhances the extraction of metals [6-9].

The application of mixtures of collectors is one of the methods to achieve the desired ratio in each case of amounts of chemically and physically adsorbed collector on the surface of floated mineral. 
At present recycling involves rebellious ores and technogenic raw characterized by low content of valuable components, fine impregnation of mineral complexes and similar technological properties of the constituent minerals.

To achieve high technological results is important to prepare old tailings before enrichment operations. Preparations may include regrinding of tailings, fractionation, desliming and washing $[10-12]$.

The development of effective technologies of extraction of minerals of non-ferrous and noble metals is one of the priorities for concentrating industry in Russia and Kazakhstan. These tasks are optimized within the framework of agreements on scientific cooperation, and the need for complete and integrated development of different deposits, ensuring high profitability of the enterprises, improving ecological environment in the mining regions determine relevance of scientific researches toward intensification of methods and ways of extraction of valuable components from rebellious and technogenic raw [13-14].

\section{Experimental Procedure}

We studied the possibility of processing flotation tailings from Zhezkazgan concentrating plant and flotation tailings from Tishinskoe deposit with the use of the combined collector. As the combined collector we selected a reagent mixture, which collective ability depends on $\mathrm{pH}$. This allows selective separation of sulfide minerals with similar physical and chemical properties. Therefore the following initial reagents were used: butyl xanthate (BX), thionocarbamates TS-1000 and composite aerofloat.

The raw for the composite aerofloat was a composite mixture of $\mathrm{C}_{3} \mathrm{H}_{7}-\mathrm{C}_{6} \mathrm{H}_{13}-\mathrm{OH}$ alcohols extracted from the dried alcohol fraction of fusel oil. According to the fractional distillation of the fusel oil, the main component of dry fusel oil was isoamyl alcohol more than $80 \%$.

Our experiments presented that the fusel oil in the reaction with pentasulphide phosphorus behaved as isoamyl alcohol.

The production of composite aerofloat proceeded in two stages. The first step production of dialkyldithiophosphoric acid (so-called acid ester) by reaction of pentasulfide phosphorus with dried alcohol fraction $\mathrm{C}_{3} \mathrm{H}_{7}-\mathrm{C}_{6} \mathrm{H}_{13}-\mathrm{OH}$. The second stage production of sodium salt of dialkyldithiophosphoric acid by alkali neutralization. The neutralization was carried out with excessive sodium hydroxide with production of the composite aerofloat.

The advantage of the suggested combined collector compared with other known reagents is that they contain two polar groups and a long hydrocarbon radical. We chose the opti- mal ratio of reagents in the composition of the combined collector, which made the composite aerofloat: thionocarbamates TC-1000: butyl sodium xanthate $=1: 1: 3$.

We studied the possibility of processing flotation tailings from Zhezkazgan concentrating plant and flotation tailings from Tishinskoe deposit with the use of the combined collector [15]. We studied the mineral and granulometric composition of flotation tailings from Zhezkazgan concentrating plant and developed the flotation modes using basic flotation reagents. According to the results of chemical analysis the Zhezkazgan tailings contain $0.13 \%$ copper; $0.01 \%$ lead; $0.01 \% \mathrm{Zn} ; 66.31 \% \mathrm{SiO}_{2}$; $2.3 \%$ total iron; $11.8 \% \mathrm{Al}_{2} \mathrm{O}_{3} ; 5.96 \% \mathrm{CaO} ;<0,0003 \% \mathrm{Cd}$; $0.16 \%$ sulfur.

The methods of study are mineralogical analysis , X-ray phase analysis ( $X$-ray diffractometer D 8 ADVANCE); X-ray fluorescence analysis (XRF spectrometer with wave dispersion Venus 200 PANalyical B. V. Holland), chemical analysis, flotation ( at flotation machines FL-290, FM-1, FM-2 (Russia).

\section{Results and Discussion}

We conducted dispersion analysis of the tailings and studied the distribution of copper and iron by size class. The results of the analysis are presented in Table 1.

Table 1 shows that the main part of copper $(72.43 \%)$ is within $-74+50 \mathrm{mcm}$ size class, and in the smaller $10 \mathrm{mcm}$ class $(17.2 \%)$.

We conducted researches on improvement of technological modes of flotation of tailings from Zhezkazgan concentrating plant with the use of basic and combined collectors. The scheme of flotation of tailings from Zhezkazgan concentrating plant with production of draft copper concentrate is shown in Figure 1.

We improved the modes of regrinding of tailings from the plant and determined the optimum consumption of the reagents. The flotation was carried out with separate reagents and their various combinations.

The results of the flotation of tailings from Zhezkazgan copper plant with optimal consumption of the reagents are shown in Table 2.

Table 2 shows that the application of the combined collector (mixture of composite aerofloat, thionocarbamate TC-1000 and butyl xanthate in the ratio of 1:1:3) in the flotation cycle of tailings from Zhezkazgan copper plant allows to improve the technological characteristics of the enrichment compared to other reagents.

According to the base technology using only butyl xanthate $(250 \mathrm{~g} / \mathrm{t})$ we obtained draft copper concentrate with the

Table 1. Results of dispersion analysis of flotation tailings from Zhezkazgan copper plant

Таблица 1. Результаты дисперсионного анализа хвостов флотационного обогащения Жезказганской медной фабрики

\begin{tabular}{l|c|c|c|c|c|c}
\hline \multirow{2}{*}{ Size class, mcm } & \multicolumn{2}{|c|}{ Output, \% } & \multicolumn{2}{c|}{ Content, \% } & \multicolumn{2}{c}{ Recovery, \% } \\
\cline { 2 - 6 } & $\mathrm{g}$ & $\%$ & $\mathrm{Cu}$ & $\mathrm{Fe}$ & $\mathrm{Cu}$ & $\mathrm{Fe}$ \\
\hline$-74+60$ & 82.3 & 41.15 & 0.11 & 4.68 & 42.26 & 42.52 \\
$-60+50$ & 10.1 & 5.05 & 0.64 & 3.96 & 30.17 & 4.41 \\
$-50+40$ & 10.5 & 5.25 & 0.05 & 3.6 & 2.45 & 4.17 \\
$-40+30$ & 14.5 & 7.25 & 0.04 & 3.6 & 2.71 & 5.76 \\
$-30+20$ & 8.4 & 4.2 & 0.046 & 2.88 & 1.80 & 2.67 \\
$-20+10$ & 13.8 & 6.9 & 0.053 & 4.68 & 3.41 & 7.13 \\
$-10+0$ & 60.4 & 30.2 & 0.061 & 5.0 & 17.2 & 33.34 \\
Исх. хвосты & 200 & 100 & 0.1071 & 4.53 & 100 & 100 \\
\hline
\end{tabular}




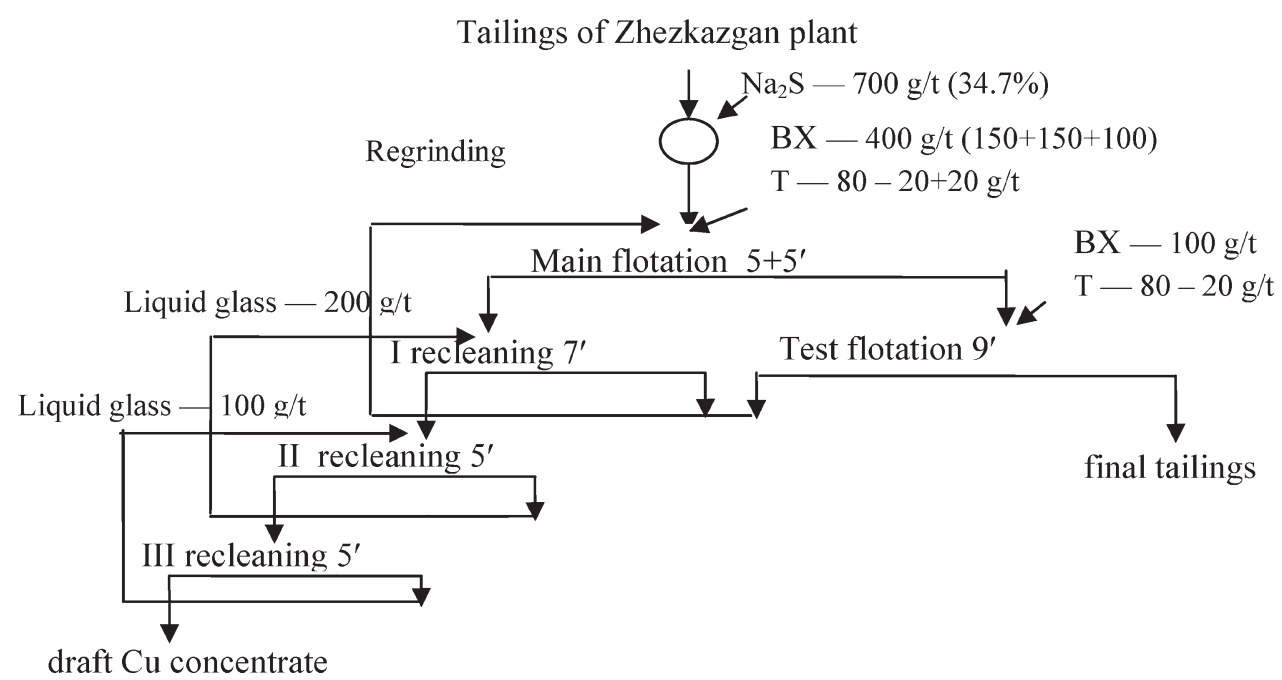

Fig. 1. Scheme of flotation of tailings from Zhezkazgan concentrating plant with production of draft copper concentrate

Рис. 1. Схема флотациихвостов обогащения Жезказганской обогатительной фабрики с получением чернового медного концентрата

Table 2. Results of flotation processing of tailings from Zhezkazgan copper plant with different reagents

Таблица 2. Результаты флотационного обогащенияхвостов Жезказганской медной фабрики с различными реагентами

\begin{tabular}{|c|c|c|c|c|c|c|}
\hline \multirow[t]{2}{*}{ Note } & \multirow{2}{*}{$\begin{array}{c}\text { Output, } \\
\%\end{array}$} & \multicolumn{2}{|c|}{ Content, $\%$} & \multicolumn{2}{|c|}{ Recovery, \% } & \multirow[t]{2}{*}{ Note } \\
\hline & & $\mathrm{Cu}$ & $\mathrm{Fe}$ & $\mathrm{Cu}$ & $\mathrm{Fe}$ & \\
\hline Draft $\mathrm{Cu}$ concentrate & 0.6 & 7.9 & 10.7 & 48.82 & 1.98 & $\mathrm{BX} 250 \mathrm{~g} / \mathrm{t}$ \\
\hline Resulted Tailings & 99.4 & 0.05 & 3.2 & 51.18 & 98.02 & \\
\hline Initial flotation tailings & 100 & 0.097 & 3.25 & 100 & 100 & \\
\hline Draft $\mathrm{Cu}$ concentrate & 0.8 & 5.2 & 9.8 & 45.61 & 2.49 & Compositional aerofloat \\
\hline Resulted Tailings & 99.2 & 0.05 & 3.1 & 54.39 & 97.51 & 300 \\
\hline Initial flotation tailings & 100 & 0.091 & 3.15 & 100 & 100 & \\
\hline Draft $\mathrm{Cu}$ concentrate & 0.6 & 10.5 & 10.2 & 67.87 & 1.83 & thionocarbamate \\
\hline Resulted Tailings & 99.4 & 0.03 & 3.3 & 32.13 & 98.17 & $60 \mathrm{~g} / \mathrm{t}$ \\
\hline Initial flotation tailings & 100 & 0.093 & 3.34 & 100 & 100 & \\
\hline Draft $\mathrm{Cu}$ concentrate & 0.65 & 8.6 & 10.9 & 58.45 & 2.18 & BX + comp. aerofloat \\
\hline Resulted Tailings & 99.35 & 0.04 & 3.2 & 41.55 & 97.82 & 1 \\
\hline Initial flotation tailings & 100 & 0.096 & 3.25 & 100 & 100 & \\
\hline Draft $\mathrm{Cu}$ concentrate & 0.62 & 12.1 & 10.7 & 76.65 & 2.11 & $\mathrm{BX}+$ \\
\hline Resulted Tailings & 99.38 & 0.023 & 3.1 & 23.35 & 97.89 & thionocarbamate \\
\hline Initial flotation tailings & 100 & 0.098 & 3.15 & 100 & 100 & \\
\hline Draft $\mathrm{Cu}$ concentrate & 0.68 & 10.9 & 11.5 & 74.91 & 2.48 & Comp.aerofloat + \\
\hline Resulted Tailings & 99.32 & 0.025 & 3.1 & 25.09 & 97.52 & $\begin{array}{l}\text { thionocarbamate } \\
90 \mathrm{~g} / \mathrm{t}\end{array}$ \\
\hline Initial flotation tailings & 100 & 0.099 & 3.16 & 100 & 100 & \\
\hline Draft $\mathrm{Cu}$ concentrate & 0.62 & 13.0 & 9.6 & 80.22 & 1.78 & Combined collector \\
\hline Resulted Tailings & 99.38 & 0.02 & 3.3 & 19.78 & 98.22 & $25 \mathrm{~g} / \mathrm{t}$ \\
\hline Initial flotation tailings & 100 & 0.100 & 3.34 & 100 & 100 & \\
\hline
\end{tabular}

copper content $7.9 \%$ at recovery $48.82 \%$. Application of thionocarbamate $(60 \mathrm{~g} / \mathrm{t})$ and its combination with butyl xanthate can increase copper content in the draft copper concentrate to $12.1 \%$ and copper recovery to $76.65 \%$.

The best results of the content and recovery of copper from the tailings of Zhezkazgan copper plant were achieved with the use of the combined collector, which consumption was much lower than the base reagent $(25 \mathrm{~g} / \mathrm{t})$. This application resulted in draft copper concentrate with the copper content $13.0 \%$, recovery $80.22 \%$.

The action of the combined collector was tested during flotation of tailings from Tishinskoe deposit. According to the results of chemical analysis the sample from the studied.

Tishinskoe tailings contained $0.05 \%$ copper; $0.06 \%$ lead; 
$1.1 \%$ zinc; $52.3 \% \mathrm{SiO}_{2} ; 2.3 \%$ iron; $8.1 \% \mathrm{Al}_{2} \mathrm{O}_{3} ; 2.5 \% \mathrm{CaO}$; $8.7 \% \mathrm{MgO}$. The dispersion analysis of tailings from Tishinskoe deposit showed that the most part of useful components - copper, lead and zinc were concentrated in the fraction $010 \mathrm{mcm}$.

The flotation scheme included regrinding of tailings, basic, control flotations and four recleanings of collective copper-lead-zinc concentrate.

We selected optimum mode of regrinding, consumption of collector and foaming agent in the cycle of collective copper-lead-zinc flotation of tailings from Tishinskoe deposit. At the optimum regrinding of tailings to $75.0 \%$ of class $0.040 \mathrm{~mm}$, collector consumption $150 \mathrm{~g} / \mathrm{t}$, T-92 foaming agent $-80 \mathrm{~g} / \mathrm{t}$ we obtained the collective copper-lead-zinc concentrate containing $2.5 \%$ copper at recovery $61.7 \% ; 2.0 \%$ lead at recovery $59.52 \%$; $4.3 \%$ of zinc at recovery $59.41 \% ; 8.3 \%$ of iron at recovery $40.4 \% ; 5.8 \mathrm{~g} / \mathrm{t}$ of gold at recovery $53.41 \%$.

The application of the combined collector (mixture of composite aerofloat, TC-1000 thionocarbamate and butyl xanthate in ratio of 1:1:3) improves the extraction of useful components into the collective copper-lead-zinc concentrate produced from tailings of Tishinskoe deposit reducing the consumption of foaming agent T- 92 to $25 \%$, from 80 to $60 \mathrm{mg} / \mathrm{kg}$ (Table 3).

With the use of the combined collector we produced the collective copper-lead-zinc concentrate containing $2.2 \%$ copper at recovery $76.74 \% ; 1.8 \%$ lead at recovery $70.43 \% ; 3.3 \%$ zinc at recovery $71.22 \%$. Extraction of copper increased at $9.63 \%$, lead $-8.41 \%$; zinc $-9.2 \%$.

At that the consumption of the combined collector was $50 \mathrm{~g} / \mathrm{t}$ less than sodium butyl xanthate, the consumption of base foaming agent decreased at $25 \%$.

\section{Conclusions}

On the basis of complex studies we chose the selective combined collector consisting of mixture of composite aerofloat, TC-1000 and butyl xanthate. The reagent ratio was 1:1:3.

The advantage of the suggested flotation reagent is that it incorporates two polar groups and a long hydrocarbon radical.

The reagent action was studied with the flotation tailings from Zhezkazgan concentrating plant and tailings from Tishinskoe deposit. It was shown that the flotation of tailings from Zhezkazgan plant with smaller, compared with butyl xanthate, consumption of combined collector resulted in the draft copper concentrate with copper content $13.0 \%$ at recovery $80.22 \%$. Compared to the basic technology the copper content increased at $5.1 \%$ in the draft concentrate, recovery at $31.4 \%$. The flotation of tailings from Tishinskoe deposit resulted in increasing extraction of copper at $9.63 \%$, lead - at $8.41 \%$; zinc - at $9.2 \%$.

\section{References}

1. Abramov A. A., Onal G. Requirements of theory and technology to the surface state of minerals to be floated, Proc. X IMPC. Izmir (Turkey), September 2004.

2. Abramov A. A. Proc. VI IMPS. Changing Scopes in Mineral Processing, ed. M. Kemal, V. Arslan, A. Akar, M. Canbazoglu. Rotterdam: Balkema, 1996, pp.181-186.

3. Alan N. Buckley, Gregory A. Hope, Kenneth C. Lee, Eddie A. Petrovic, Ronald Woods Adsorption of O-isopropyl$\mathrm{N}$-ethyl thionocarbamate on $\mathrm{Cu}$ sulfide ore minerals. Minerals Engineering. 2014, Vol. 69, pp. 120-132.

4. Abramov A. A. Fiz.-tehn. probl. razrab. polez. Iskop (Physical technical problems of development of natural resources). 2005, No. 1, pp. 4-14.

5. Otrozhdennova L. A., Rjaboj V. I., Kuchaev V. A., Malinovskaja N. D. Flotacija mednyh sul'fidnyh rud geksilovym ksatogenatom firmy «Hjohst»(Flotation of copper sulphide ores by hexyl xatogenate from Hohst company). Obogashhenie rud, 2010, No. 4.

6. Rjaboj V. I., Kretov V. P., Smirnova E. Ju. Ispolzovanie dialkilditiofosfatov pri flotacii sulfidnyh rud (Usageof dialkyldithiophosphates at flotation of sulphide ores). Proceedings, Moscow, MISiS, V. 2, pp. 496-498.

7. Asonchik K. M., Rjaboj V. I. Razrabotka tehnologii obogashhenija medno-cinkovoj rudy s polucheniem mednogo koncentrata vysokogo kachestva (Development of technology of concentration of copper-zinc ores with production of copper concentrate of high quality). Obogashhenie rud, 2009, No. 1.

8. Rjaboj V. I., Asonchik K. M., Pol'kin V. N. i dr. Primenenie selektivnogo sobiratelja priflotacii medno-cinkovyh rud (Application of selective collector at flotation of copper-zinc ores). Obogashhenie rud. 2008, No. 3, pp. 20-22.

9. Rjaboj V. I, Shenderovich V. A., Krepetov V. P. Primenenie ajeroflotov priflotacii rud (Application of aerofloats at flotation of ores). Obogashhenie rud. 2005, No. 6, pp. 43-44.

10. Bocharov V. A., Ignatkina V. A., Hachatrjan L. S. Pererabotka piritnyh tehnogennyh produktov (Processing of pyrite technogenic products) Proceedings, Moscow, MISiS, V. 1, pp. $122-125$.

11. Xumeng Chen, Yongjun Peng, Dee Bradshaw The effect of particle breakage mechanisms during regrinding on the subsequent cleaner flotation. Minerals Engineering. 2014. Vol. 66-68, pp. 157-164.

12. Bocharov V. A., Ignatkina V. A. Racionalnye tehnologii flotacii trudnoobogatimyh kolchedannyh rud cvetnyh metallov (Rational technologies of flotation of rebellious pyrite ores of color metals).Proceedings: Novye tehnologii obogashhenija i kompleksnoj pererabotki trudnoobogatimogo prirodnogo i

Table 3. Results of flotation of tailings from Tishinskoe deposit

Таблица 3. Результаты флотационного обогащенияхвостов Тишинского месторождения

\begin{tabular}{l|c|c|c|c|c|c|c|l}
\hline \multirow{2}{*}{ Products } & Output, \% & \multicolumn{3}{c|}{ Content, \%, g/t } & \multicolumn{3}{c|}{ Recovery, \% } & Note \\
\cline { 3 - 8 } & & $\mathrm{Cu}$ & $\mathrm{Pb}$ & $\mathrm{Zn}$ & $\mathrm{Cu}$ & $\mathrm{Pb}$ & $\mathrm{Zn}$ & \\
\hline Coll.concentrate & 2.0 & 2.0 & 1.6 & 3.2 & 67.11 & 62.02 & 62.02 & Base \\
Resulted tailings & 98 & 0.02 & 0.02 & 0.04 & 32.89 & 37.98 & 37.98 & technologies: \\
Initial tailings & 100 & 0.060 & 0.052 & 0.103 & 100 & 100 & 100 & $\mathrm{BX}-150 \mathrm{~g} / \mathrm{t}$ \\
\hline Coll.concentrate & 2.2 & 2.2 & 1.8 & 3.3 & 76.74 & 70.43 & 71.22 & Combined \\
Resulted tailings & 97.8 & 0.015 & 0.017 & 0.03 & 23.26 & 29.57 & 28.78 & collector - \\
Initial tailings & 100 & 0.063 & 0.056 & 0.102 & 100 & 100 & 100 & $\mathrm{~g} / \mathrm{t}-92-60 \mathrm{~g} / \mathrm{t}$ \\
\hline
\end{tabular}


tehnogennogo mineral'nogo syr'ja. (Plaksinskie chtenija 2011), 2011, pp. 17-22.

13. Chanturija V. A., Kozlov A. P. Progressivnye tehnologii kompleksnoj i glubokoj pererabotki prirodnogo i tehnogennogo mineralnogo syrja (Progressive technologies of complex and deep processing of natural and technogenic mineral raw). Proceedings «Kombinirovannye processy pere-rabotki mineralnogo syrja: Teorija i praktika», Nacionalny mineralno-syrevoj universitet «Gornyj», St. Petersburg, 2015, pp. 12.

14. Rudoj G. N., Volkova N. A., Shadrunova I. V., Zelinskaja I. V. Tehnologicheskie, jekonomicheskie $i$ jekologicheskie aspekty pererabotki tehnogennogo syrja gornometallurgicheskih predprijatij (Technological, economical and ecological aspects of processing of technogenic raw of metallurgical plant). Proceedings: Novye tehnologii obogashhenija i kompleksnoj pererabotki trudnoobogatimogo prirodnogo i tehnogennogo mineranogo syrja (Plaksinskie chtenija - 2011), 2011, pp. 6-12.

15. Musina M. M., Shautenov M. R., Tusupbaev N. K., Turysbekov D. K., Semushkina L. V., Muhamedilova A. M. Flotacija hvostov s primeneniem jekologicheski bezopasnyh polifunkcional'nyh flotoreagentov (Flotation of tails with application of ecologically safe polyfunctional flotation reagents). Vestnik KazNTU. 2014, No. 4, pp. 363-369.

\section{Литература}

1. AbramovA. A., Onal G. Requirements of theory and technology to the surface state of minerals to be floated // Proc. X IMPC. Izmir (Turkey), September 2004.

2. Abramov A. A. // Proc. VI IMPS. Changing Scopes in Mineral Processing // ed. M. Kemal, V. Arslan, A. Akar, M. Canbazoglu. Rotterdam: Balkema, 1996. P. 181-186.

3. Alan N. Buckley, Gregory A. Hope, Kenneth C. Lee, Eddie A. Petrovic, Ronald Woods Adsorption of O-isopropyl-N-ethyl thionocarbamate on $\mathrm{Cu}$ sulfide ore minerals // Minerals Engineering. 2014. Vol. 69. P. 120-132.

4. Абрамов А. А. // Физ.-техн. пробл. разраб. полез. ископ. 2005. № 1. С. 4-14.

5. Отрожденнова Л. А., Рябой В. И., Кучаев В. А., Малиновская Н. Д. Флотация медных сульфидных руд гексиловым ксатогенатом фирмы «Хёхст» // Обогащение руд. 2010. № 4.

6. Рябой В. И., Кретов В. П., Смирнова Е. Ю. Использование диалкилдитиофосфатов при флотации сульфидных руд // Материалы IX Конгресса обогатителей стран СНГ, Москва, МИСиС, 2013. Т. 2. С. 496-498.
7. Асончик К. М., Рябой В. И. Разработка технологии обогащения медно-цинковой руды с получением медного концентрата высокого качества //Обогащение руд. 2009. № 1.

8. Рябой В. И., Асончик К. М., Полькин В. Н. и др. Применение селективного собирателя при флотации медноцинковых руд //Обогащение руд. 2008. №3. С. 20-22.

9. Рябой В. И., Шендерович В. А., Крепетов В. П. Применение аэрофлотов при флотации руд // Обогащение руд. 2005. № 6. С. 43-44.

10. Бочаров В. А., Игнаткина В. А., Хачатрян Л. С. Переработка пиритных техногенных продуктов // Материалы IX Конгресса обогатителей стран СНГ, Москва, МИСиС, 2013. Т.1. С. 122-125.

11. Xumeng Chen, Yongjun Peng, Dee Bradshaw The effect of particle breakage mechanisms during regrinding on the subsequent cleaner flotation // Minerals Engineering. 2014. Vol. 66-68. P. 157-164.

12. Бочаров В. А., Игнаткина В. А. Рациональные технологии флотации труднообогатимых колчеданных руд цветных металлов // Мат. Межд. совещания «Новые технологии обогащения и комплексной переработки труднообогатимого природного и техногенного минерального сырья» (Плаксинские чтения - 2011), 2011. C. $17-22$.

13. Чантурия В. А., Козлов А. П. Прогрессивные технологии комплексной и глубокой переработки природного и техногенного минерального сырья // Материалы Международной научно-технической конференции «Комбинированные процессы переработки минерального сырья: Теория и практика», Национальный минерально-сырьевой университет «Горный», Санкт-Петербург, 2015. С. 12.

14. Рудой Г. Н., Волкова Н. А., Шадрунова И. В., Зелинская И. В. Технологические, экономические и экологические аспекты переработки техногенного сырья горно-металлургических предприятий // Мат. Межд. совещания «Новые технологии обогащения и комплексной переработки труднообогатимого природного и техногенного минерального сырья» (Плаксинские чтения - 2011), 2011. C. $6-12$.

15. Мусина М. М., Шаутенов М. Р., Тусупбаев Н. К., Турысбеков Д. К., Семушкина Л. В., Мухамедилова А. М. Флотация хвостов с применением экологически безопасных полифункциональных флотореагентов // Вестник КазНТУ. 2014. № 4. С. 363-369. 